\title{
Characterization of entomopathogenic fungi as a natural biological control of American cockroaches (Periplaneta americana)
}

\author{
EMANTIS ROSA^, C.N. EKOWATI, TUNDJUNG TRIPENI HANDAYANI, AHMAD IKHSANUDIN, \\ FERLY APRILIANI, ACHMAD ARIFIYANTO \\ Department of Biology, Faculty of Mathematics and Natural Sciences, Universitas Lampung. Jl. Prof. Soemantri Brojonegoro No. 1, Bandar Lampung \\ 35144, Rajabasa, Lampung, Indonesia, Tel.: +62-721-704625, Fax.: +62-721-704625, ^email: emantisrosa@gmail.com, \\ achmad.arifiyanto@fmipa.unila.ac.id
}

Manuscript received: 1 September 2020. Revision accepted: 19 October 2020

\begin{abstract}
Rosa E, Ekowati CN, Handayani TT, Ikhsanudin A, Apriliani F, Arifiyanto A. 2020. Characterization of entomopathogenic fungi as a natural biological control of American cockroaches (Periplaneta americana). Biodiversitas 21: 5276-5282. Eradicating cockroaches using chemical insecticides produces residues that contaminate the environment and promote insect resistance. Biological control has become an option for controlling cockroaches. The use of entomopathogenic fungi is one of them. The aim of this study was to obtain a fungal isolate that was effective at killing cockroaches. The result of entomopathogenic fungi isolation from cockroaches obtained 4 isolates, IK1, IK2, IK3 isolates were included in the Aspergillus genus while IK4 was Penicillium. Extracellular enzymes serve as screening materials for biocontrol candidates. IK1 and IK3 isolates showed higher chitinase activity than the other two isolates. The highest mortality of Periplaneta americana at nymphs stage was $60 \%$ achieved by the treatment of Aspergillus sp. IK3 with a concentration of 109 conidia/mL. In adult stage cockroach the mortality was increased to $86 \%$.
\end{abstract}

Keywords: Aspergillus, biological control, cockroaches, entomopathogenic fungi, nymphs

\section{INTRODUCTION}

Cockroaches are vectors of disease. Their bodies have been shown to carry not only parasites (Atiokeng Tatang et al. 2017) but also a number of antibiotic-resistant pathogenic bacteria (Moges et al. 2016). They were found both indoors (kitchen and toilet) and outdoors (drainage and sewer). Environment condition and organic matter of these habitats were attracted to feed. Cockroach contact with a number of household items due to their mobility has increased the risk of pathogen transmission to humans (Yusof 2018).

Parasites and pathogenic bacteria carried by cockroaches cause diseases in humans such as toxocariasis, pneumonia, urinary tract infections, dysentery, and diarrhea. In people with asthma and rhinitis, cockroaches also cause allergic reactions. To minimize above diseases cockroach control is required properly. Control was carried out either mechanically, chemically or biologically. Mechanical control constrained by the mobility of cockroaches and their populations (Mongeau et al. 2014; Sanchez et al. 2015). Chemical control was a promising solution. Zahraei-Ramazani et al. (2018) reported that $90 \%$ of the American cockroach (Periplaneta americana) population has been successfully controlled, using chemical control. Unfortunately, this treatment also threatened non-target insects and resulted in resistance vectors and produced residues that pollute the environment (Nicolopoulou-Stamati et al. 2016).

Entomopathogenic fungi, was unconventional applications (Litwin et al. 2020)of the biological control options in controlling cockroaches. It has several advantages such as affordable cost, high yield, and not interfere the environment with the residue (Mantzoukas and Eliopoulos 2020). EPF collected from agricultural soil samples (Robles-acosta et al. 2019), rhizosphere of maize plants (Nelly et al. 2019), and soils and Ixodes scapularis (Tuininga et al. 2009). Several studies reported that entomopathogenic fungi such as Aspergillus sp, Geotrichum sp., and Penicillium sp., have been used as bioinsecticides against house flies (Musca domestica) in larval stage (Septiana et al. 2019), Mucor sp., Penicillium sp., Aspergillus sp., as a control for adult mosquitoes (Aedes aegypti) (Supiyanto et al. 2019) and Metharizium anisopliae as a control for the German cockroach population (Blattella germanica) (Lopes et al. 2013). Entomopathogenic fungi information on Periplaneta americana is still limited. The aims of this study were to determine the enzymatic characteristics of entomopathogenic fungi and their effect on the number of deaths in nymphs and adult stage of $P$. americana. 


\section{MATERIALS AND METHODS}

\section{Isolation and identification of entomopathogenic fungi}

Entomopathogenic fungi were isolated from the body parts of $P$. americana by a moist chamber method. The moist chamber method was carried out by immersing the body parts of the P. americana cockroach in $70 \%$ alcohol for 30 seconds and sterile distilled water twice consecutively for 2 minutes for surface sterilization. It placed on moistened tissue in a Petri dish. It incubated at $28^{\circ} \mathrm{C}$ for 3-5 days (Jain et al. 2020)

Entomopathogenic fungi that grown were cultured at Potato Dextrose Agar. They were purified and followed by morphological observation using a slide culture (72 hours) completed with the data of the mycelium, conidia, and conidia-producing bodies. The characteristics were compared with them (Barnet and Hunter 1998).

\section{Colloidal chitin preparation}

Chitin powder $(5 \mathrm{~g})$ was weighed and dissolved in 80 $\mathrm{mL}$ of concentrated $\mathrm{HCl}$. The mixture was homogenized using a magnetic stirrer for 30 minutes and allowed to stand at $4^{\circ} \mathrm{C}$ for 24 hours. The mixture was filtered using glass wool. The filtrate obtained was added with $40 \mathrm{~mL}$ of cold distilled water and then homogenized using a magnetic stirrer. The $\mathrm{pH}$ was adjusted with the addition of $12 \mathrm{~N} \mathrm{NaOH}$ to close to 7 . The mixture was centrifuged at $7.500 \mathrm{rpm}$ for 15 minutes. The filtrate obtained was separated from the supernatant and added with cold distilled water. It was again centrifuged at $7500 \mathrm{rpm}$ for 15 minutes. The filtrate obtained was colloidal chitin (Suryadi et al. 2016).

\section{Entomopathogenic fungi chitinolytic activity}

The chitinolytic ability of entomopathogenic fungi was tested using a mixture of PDA media with $1 \%$ colloidal chitin. The media was sterilized in an autoclave for 15 minutes. Media that has been sterile added $500 \mathrm{mg} / \mathrm{L}$ of chloramphenicol. The media was poured into sterile Petri dishes. Entomopathogenic fungi isolate was inoculated into the test medium using a needle loop, after the media had solidified. Chitinolytic activity was detected by the formation of a clear zone around the fungus colony. The clear zone was visualized by sprinkling $0.1 \%$ congo red and washed using $1 \mathrm{M} \mathrm{NaCl}$ (Suryadi et al. 2016).

\section{Entomopathogenic fungi lipolytic and proteolytic activity}

Lipolytic test was carried out by growing entomopathogenic fungi on PDA media with $1 \%$ olive oil, $0.04 \%$ methyl red, and $1.5 \%$ Tween 80 . Proteolytic test conducted at PDA media supplemented with $1 \%$ skim milk that has been pasteurized at $60^{\circ} \mathrm{C}$ for 15 minutes. Lipolytic and proteolytic activity was detected by the formation of clear zones around the fungal colonies (Choudhary and Jain 2012).

\section{Enzymatic index}

The enzymatic index was determined using a modified formula from the research of Lechuga et al. (2016):

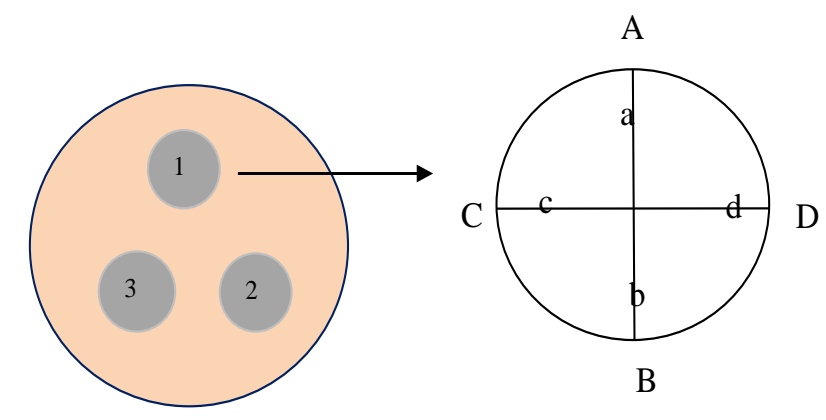

Figure 1. Measurement of colony diameter and clear zone diameter for enzymatic index determination

Note:

$\mathrm{AB}, \mathrm{CD} \quad$ : Clear Zone Diameter

$\mathrm{ab}, \mathrm{cd}$

Average Clear Zone Diameter $(\mathrm{Dz}) \quad:(\mathrm{AB}+\mathrm{CD}) / 2$

Average Colony Diameter (Dk) $\quad:(\mathrm{ab}+\mathrm{c}) / 2$

Average Total Clear Zone Diameter (RDz): $(\mathrm{Dz} 1+\ldots+\mathrm{Dzn}) / \mathrm{n}$

Average Total Colony Diameter $(\mathrm{RDk}):(\mathrm{Dk} 1+\ldots+\mathrm{Dkn}) / \mathrm{n}$

The amount of the Enzymatic Index (IE) was determined based on the comparison of the average total diameter of the clear zone with the average total colony diameter with the following formula:

$\mathrm{IE}=(\mathrm{RDz}-\mathrm{RDk}) / \mathrm{RDk}$

Note* length in millimeter

\section{Rearing nymphs of Periplaneta americana}

Periplaneta americana nymphs were obtained from people's homes and reared in "rearing boxes" in the laboratory. They were fed bird feed pellets. Their egg sac was kept in a separate container until it hatches and then the nymphs that come out are separated into a new container. The test insects used were instar 3 nymphs (Arifah et al. 2016).

\section{Fungal suspensions preparation}

Sterile distilled water was poured into a test tube containing 14 days old entomopathogenic fungi. To the test tube $1 \%$ molasses and $0.5 \mathrm{~mL}$ Tween 80 were added. It was homogenized using a vortex mixer. Conidia density is calculated using a hemocytometer with a light microscope with a 400x magnification, with the following formula (Yunizar 2018):

$$
\mathrm{C}=\left(\mathrm{t} \times 10^{6}\right) /(\mathrm{n} \times 0.25)
$$

Where:

C : The density of conidia per $\mathrm{ml}$ of solution

$\mathrm{t}$ : The total number of conidia in the sample box was observed

$\mathrm{n} \quad$ : The number of sample boxes used

0.25 : Small-scale sample box correction factor

The conidia suspension was further diluted at densities of $10^{7}, 10^{8}$, and $10^{9}$ conidia $/ \mathrm{mL}$. 


\section{Mortality test of entomopathogenic fungi toward Periplaneta americana}

The cockroach nymph mortality was tested using dip insect method. It was modified from the (Gutierrez et al. 2015). Nymphs were immersed in a conidia solution with concentration whereas using the dip insect method with 3 mL conidia concentrations of $10^{7}, 10^{8}$, and $10^{9}$. Conidial suspension composed of 7 days entomopathogenic fungi spores that diluted in water. It applied to each cockroach nymph and adult. This test was repeated 3 times and observed every 72, 96, 120 hours.

\section{RESULTS AND DISCUSSION}

Based on the results of macroscopic observations IK1, IK2, and IK3 isolates had colony characteristics with black color and different growth rates. Isolates IK4 was the smallest diameter in colony growth (Figure 2). In the three isolates of Aspergillus sp. had the same characteristics but there were differences in the size of the conidia (Table 1).

From the data obtained (Table 2), the highest mortality of $P$. americana nymphs was $60 \%$ in the treatment of Aspergillus sp. IK3 with a concentration of $10^{9}$ conidia/mL was compared to control, whereas in the treatment of Aspergillus sp. The highest IK1 mortality of $P$. americana nymphs was $46 \%$ with a concentration of $10^{9}$ conidia $/ \mathrm{mL}$. Based on the results of the ANOVA test $(\alpha=5 \%)$, The type of entomopathogenic fungi isolates on the mortality percentage of $P$. americana nymphs did not show any significant differences. Although the mortality rate due to entomopathogenic fungi was low, the treatment of entomopathogenic fungi spores was proven to be able to kill cockroach nymphs (Figure 3 ).

Based on the results of the ANOVA test $(\alpha=5 \%)$ (Table 4) that followed by Duncan double hose further test (Table 3), the type of entomopathogenic fungi isolates on the mortality percentage of $P$. americana nymphs was shown any significant differences. Aspergillus sp. 3 caused mortality to adult $P$. americana which was $86 \%$ higher than that of Aspergillus sp. 1 which was only $60 \%$. The administration of entomopathogenic fungi spores was even more effective in killing adult cockroaches (Figure 4). This can be seen from the large percentage of deaths at spore density $10^{9}$ when compared to the same density at the nymph stage.

Figure 5 informed that the highest chitinolytic index was produced by Aspergillus sp. 3 equal to 0.33 EI. Isolate Aspergillus sp. 3 was also an isolate that produced the largest clear zone diameter of $50 \mathrm{~mm}$. The highest proteolytic index was produced by isolates Penicillium sp. equal to 0.50 . However, the widest clear zone was produced by Aspergillus sp. 3 isolates, namely $34.7 \mathrm{~mm}$, larger than the clear zone of Penicillium sp. ie $15 \mathrm{~mm}$ (Figure 6). The highest lipolytic index was produced by isolate Penicillium sp. equal to 0.31. Unfortunately, the largest clear zone diameter was produced by Aspergillus sp., 2 isolates, which was $18 \mathrm{~mm}$ larger than the clear zone of Penicillium sp. by $8.5 \mathrm{~mm}$.

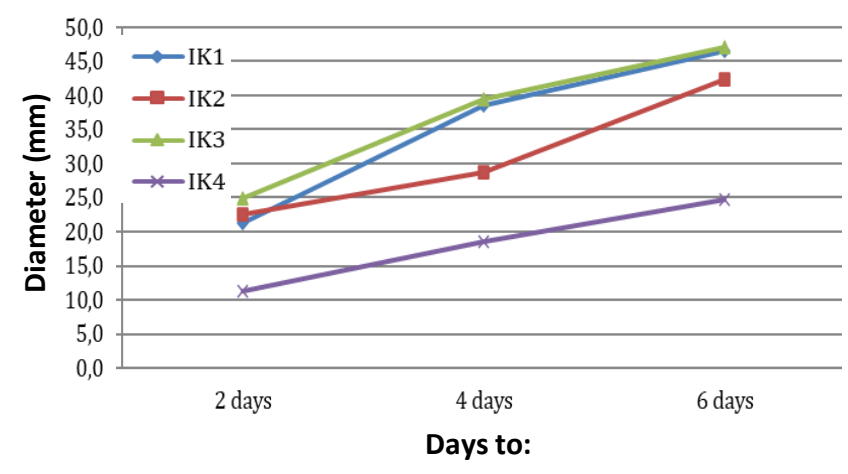

Figure 2. Colony growth of entomopathogenic fungi from cockroach (Periplaneta americana)
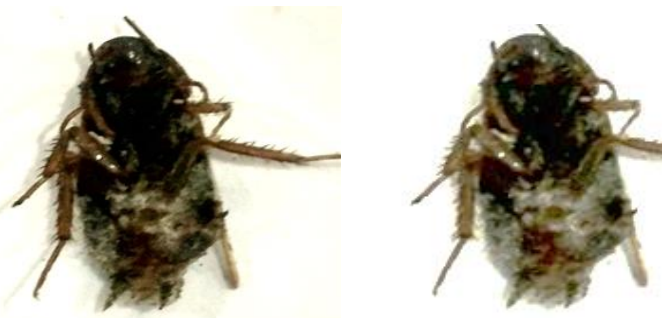

Figure 3. Morphology of Periplaneta americana nymphs after treatment (left) treatment of Aspergillus sp. 1, (right) treatment of Aspergillus sp. isolates 3
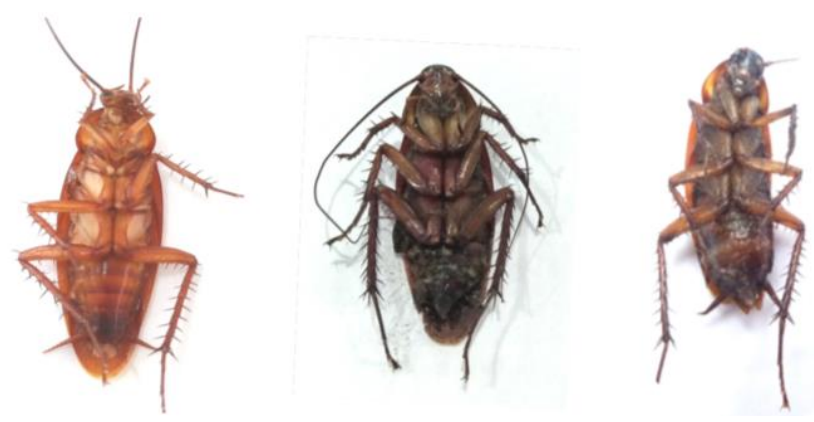

Figure 4. Morphology of Periplaneta americana adult after treatment (left) control, (middle) treatment of Aspergillus sp. 1, (right) treatment of Aspergillus sp. isolates. 3 


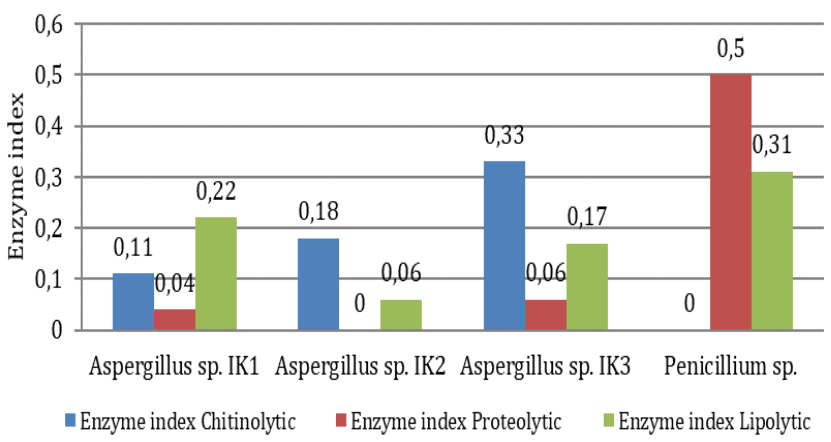

Figure 5. The performance of enzyme index of entomopathogenic fungi

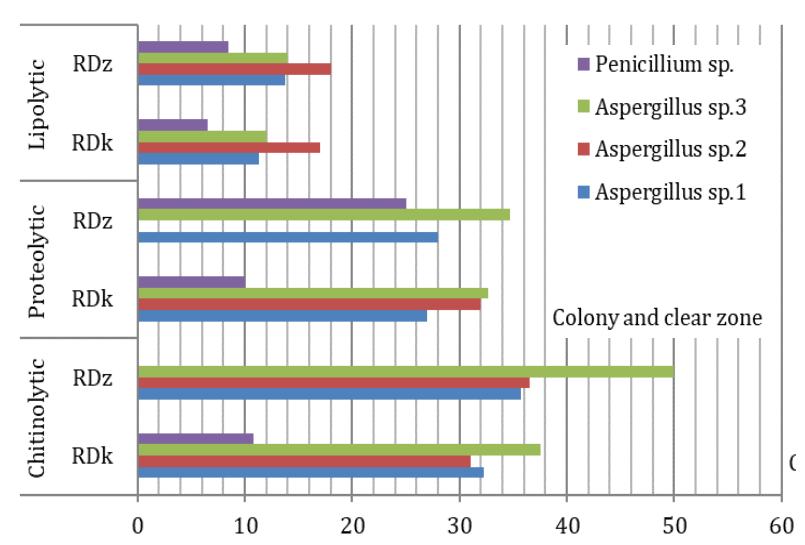

Figure 6. Colony and clear zone comparison of entomopathogenic fungi performance

Table 1. Morphology of entomopathogenic fungi from cockroach (Periplaneta americana)

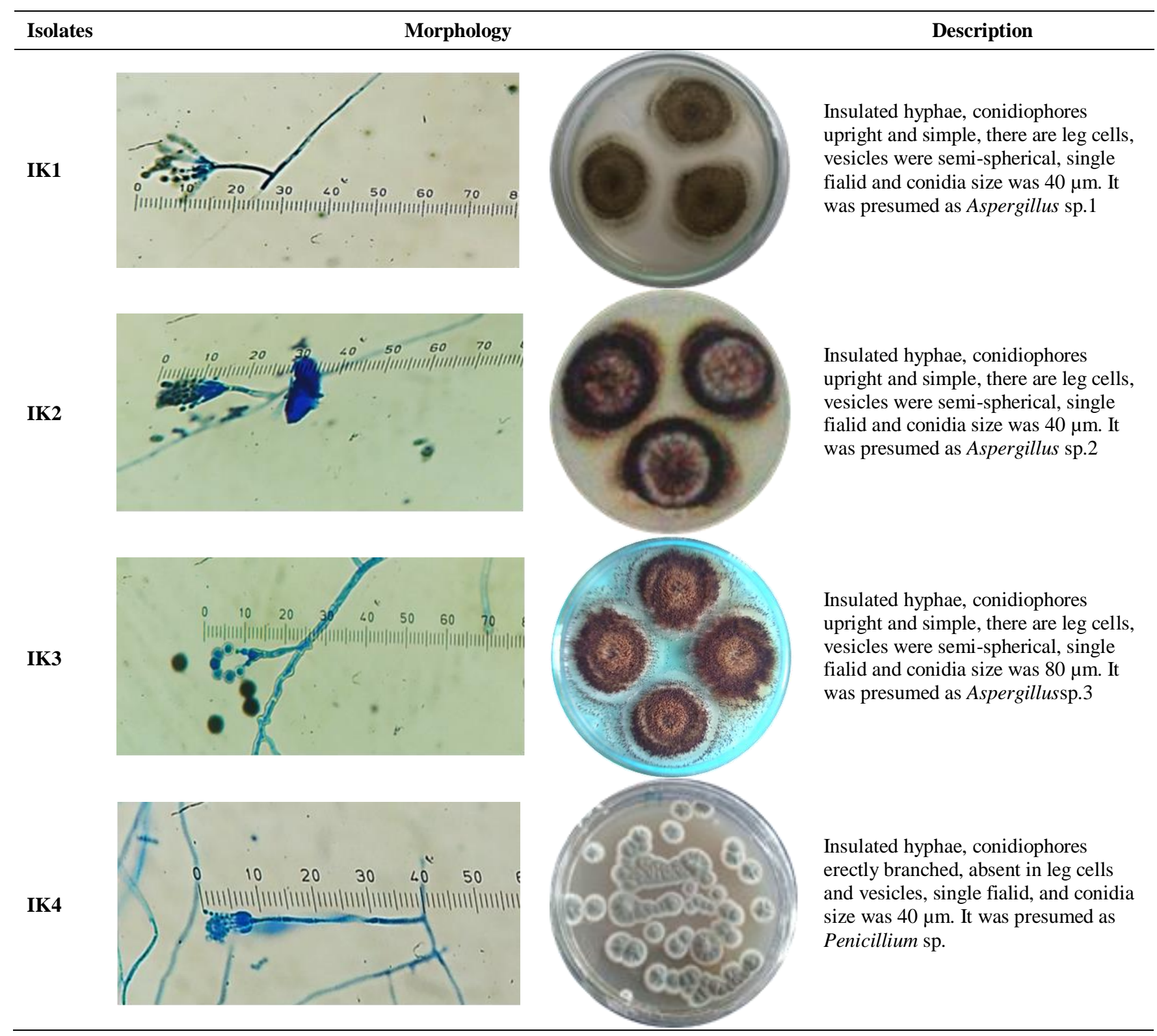


Table 2. Mortality of Periplaneta americana nymph in EPF treatment

\begin{tabular}{|c|c|c|c|c|c|c|}
\hline \multirow[t]{2}{*}{ Isolates } & \multirow{2}{*}{$\begin{array}{c}\text { Suspension } \\
\text { concentration } \\
\text { (conidia/mL) }\end{array}$} & \multicolumn{5}{|c|}{ P. americana nymph mortality } \\
\hline & & R1 & $\mathbf{R 2}$ & $\mathbf{R 3}$ & $\mathbf{A}$ & $\%$ \\
\hline$\overline{\text { Aspergillus }}$ & $10^{7}$ & 1 & 2 & 3 & 2 & 40 \\
\hline \multirow[t]{2}{*}{ IK1 } & $10^{8}$ & 1 & 1 & 1 & 1 & 20 \\
\hline & $10^{9}$ & 2 & 4 & 1 & 2.3 & 46 \\
\hline Aspergillus & $10^{7}$ & 1 & 1 & 2 & 1.3 & 26 \\
\hline \multirow[t]{2}{*}{ IK3 } & $10^{8}$ & 1 & 1 & 2 & 1.3 & 26 \\
\hline & $10^{9}$ & 2 & 3 & 4 & 3 & 60 \\
\hline Negative control & & 0 & 0 & 0 & 0 & 0 \\
\hline Vehicle control & & 0 & 0 & 0 & 0 & 0 \\
\hline
\end{tabular}

Note: R1: $1^{\text {st }}$ Repetitions, R2: $2^{\text {nd }}$ Repetitions, R3: $3^{\text {rd }}$ Repetitions, A: Average, $\%$ : Mortality percentage

Table 3. Mortality of Periplaneta americana adult in entomopathogenic fungi treatment

\begin{tabular}{|c|c|c|c|c|c|c|c|}
\hline \multirow[t]{2}{*}{ Isolates } & \multirow{2}{*}{\multicolumn{2}{|c|}{$\begin{array}{c}\text { Suspension } \\
\text { concentration } \\
\text { (conidia/mL) }\end{array}$}} & \multicolumn{5}{|c|}{ P. americana nymph mortality } \\
\hline & & & R1 & $\mathbf{R 2}$ & $\mathbf{R 3}$ & $\mathbf{A}$ & $\%$ \\
\hline Aspergillus & sp. & $10^{7}$ & 2 & 3 & 2 & 2.3 & 46 \\
\hline \multirow[t]{2}{*}{ IK1 } & & $10^{8}$ & 2 & 2 & 3 & 2.3 & 46 \\
\hline & & $10^{9}$ & 3 & 3 & 3 & 3 & 60 \\
\hline Aspergillus & sp. & $10^{7}$ & 3 & 3 & 4 & 3.3 & 66 \\
\hline \multirow[t]{2}{*}{ IK3 } & & $10^{8}$ & 4 & 5 & 3 & 4 & 80 \\
\hline & & $10^{9}$ & 4 & 4 & 5 & 4.3 & 86 \\
\hline Negative con & trol & & 0 & 0 & 0 & 0 & 0 \\
\hline Vehicle cont & & & 0 & 0 & 0 & 0 & 0 \\
\hline
\end{tabular}

Note: R1: $1^{\text {st }}$ Repetitions, R2: $2^{\text {nd }}$ Repetitions, R3: $3^{\text {rd }}$ Repetitions, A: Average, \%: Mortality percentage

Table 4. Analysis of Variance (ANOVA) Test $(\alpha=5 \%)$

\begin{tabular}{llccccc}
\hline & & $\begin{array}{c}\text { Sum of } \\
\text { Squares }\end{array}$ & Df & $\begin{array}{c}\text { Mean } \\
\text { Square }\end{array}$ & F & Sig. \\
\hline IK1 & Between Groups & .889 & 2 & .444 & 2.000 & .216 \\
& Within Groups & 1.333 & 6 & .222 & & \\
& Total & 2.222 & 8 & & & \\
IK3 & Between Groups & 1.556 & 2 & .778 & 1.400 & .317 \\
& Within Groups & 3.333 & 6 & .556 & & \\
& Total & 4.889 & 8 & & & \\
NC & Between Groups & .000 & 2 & .000 &. &. \\
& Within Groups & .000 & 6 & .000 & & \\
& Total & .000 & 8 & & & \\
VC & Between Groups & .000 & 2 & .000 &. &. \\
& Within Groups & .000 & 6 & .000 & & \\
& Total & .000 & 8 & & & \\
\hline
\end{tabular}

\section{Discussion}

Based on the results of microscopic observations in Table 1, it was found 3 fungi Aspergillus sp. and 1 Penicillium sp. The data obtained for the IK1, IK2, IK3 isolates is in accordance with the opinion of Soesanto et al. (2020) which states that the Aspergillus sp., microscopically, it has a round conidium with a bluish- green color, the head of the conidia (vesicle) is shaped like a club (clavate) or round, and becomes oval (columnar) with increasing age of the colony and has a conidia stalk (conidiophore). In addition, according to (Praja and Yudhana 2018) the fungus Aspergillus sp. have sterigmata appear to cover the upper half of the vesicles and have conidia with a serrated surface. The difference in the size of conidia (Table 1) caused by differences in gene regulation that regulate the formation of conidia through the conidia process so that gene expression is also different (Yu 2010).

IK4 isolate had different characteristics from the other three isolates. Based on the data obtained, IK4 has characteristics in accordance with the opinion of Visagie et al. (2014) that the fungal characteristics of the genus Penicillium sp. namely having hyphae with septa, conidia, sterigma, and conidia is caused by differences in gene regulation that regulate the formation of conidia through the conidia process so that gene expression is also different (Yu 2010).

The mortality test of entomopathogenic fungi used 2 isolates of fungi that had the highest chitinolytic index. In this case, the isolates used were Aspergillus sp. IK1 and Aspergillus sp. IK3. Veliz et al. (2017) emphasized that chitin was an essential component of insects and fungi exteriors. Degradation of external surfaces contains this polymer altered damage or even death of any pathogen. The clear zone formed shows the hydrolysis reaction of chitin polymer to $\mathrm{N}$-acetyl D-glucosamine monomer by the chitinase enzyme produced by the fungus. The clear zone was seen more clearly after the addition of a solution of congo red $\left(\mathrm{C}_{32} \mathrm{H}_{22} \mathrm{~N}_{6} \mathrm{O}_{6} \mathrm{~S}_{2} \mathrm{Na}_{2}\right)$ which binds to the chitin polymer in agar with $\beta 1.4 \mathrm{~N}$-acetyl-glucosamine bonds. Chitin polymer that has been hydrolyzed into N-acetyl-Dglucosamine monomers did not have $\beta 1.4 \mathrm{~N}$-acetylglucosamine bonds so that congo red did not bind strongly to these monomers which results in the formation of a clear zone around the colony. The clear zone will be seen more in contrast with the addition of $1 \mathrm{M} \mathrm{NaCl}$ which will dissolve congo red which is not strongly bonded, especially around fungal colonies (Schiavone et al. 2014).

Chitinases were particularly attractive to fungicidal, insecticidal, and nematicidal activities purposes (Berini et al. 2018). Chitin-degrading fungi including Aspergillus, Mucor, and Mortierella (Brzezinska et al. 2014). According to Utami and Ambarwati (2014) differences in the effectiveness of entomopathogenic fungi isolates in killing insects were influenced by several factors, including extracellular enzymes secreted by fungi to degrade insect bodies, the types of toxins produced, and conidia size. Based on the research that has been done, Aspergillus sp. 3 has a greater chitinolytic and proteolytic index compared to Aspergillus sp. 1 (Figure 4). This shows the ability of Aspergillus sp. 3 in secreting extracellular enzymes such as chitinase and protease is higher when compared to isolates of Aspergillus sp. 1. These enzymes are needed to penetrate the mechanical defenses of adult $P$. americana so that the entomopathogenic fungi can carry out further infection processes in the target insect's body. 
Therefore, the mortality of $P$. americana adults was higher when treated using Aspergillus sp. 3 compared to isolates of Aspergillus sp.1.

This is supported by research conducted by Dhawan and Joshi (2017) which states that the activity of extracellular enzymes produced by entomopathogenic fungi is one of the determining factors for the level of virulence. The most important enzyme in this process was chitinase, which plays a role in degrading the chitin polymer contained in insect cuticles. Direct testing of third instar Pieris brassicae larvae experienced the highest mortality after being treated using the entomopathogenic fungi Beauveria bassiana which had the highest chitinase activity.

Another enzyme activity required to penetrate the host body is protease. This enzyme will break down the protein in the insect's body into amino acids which are used for the growth of entomopathogenic fungi. Based on research conducted by Perinotto et al. (2014) entomopathogenic fungi that have higher proteolytic activity have a higher virulence level as well.

Apart from chitinase and protease activity, lipase activity is also an important part of determining the virulence of entomopathogenic fungi. Lipase functions to hydrolyze ester bonds in lipoproteins, fats, and waxes on the inside of the insect integument so that it will make it easier for entomopathogenic fungi to penetrate. This is in accordance with research conducted by Dhawan and Joshi (2017), entomopathogenic fungi that have low lipase activity, are less effective in controlling the larvae of Pieris brassicae.

Aspergillus sp. was a fungus capable of producing mycotoxins such as ochratoxin A, B, and C, aflatoxins B1, B2, G1, G2, M1, and M2 (Martindah and Bahri 2016), and fumonisin B2 (Schuster et al. 2002). According to (Zain 2011) aflatoxins are immunosuppressive which can disrupt the immune system of adult $P$. americana which is attacked by entomopathogenic fungi. Meanwhile, ochratoxin works by disrupting the nervous system of the neurons and psychomotor speed so that adult $P$. americana has slower moving speed and reduced appetite which can lead to slow death (Ratnaseelan et al. 2018).

Another factor that affects the effectiveness of the entomopathogenic fungi is the density of conidia used in the test. Based on the research that has been done, the highest mortality was found in the treatment using isolates with conidia density of $10^{9}$ conidia/mL for both types of entomopathogenic fungi. Meanwhile, the lowest mortality was found in the treatment using conidia density $10^{7}$ and $10^{8}$ conidia/mL for Aspergillus sp. 1 and $10^{7}$ conidia/mL for Aspergillus sp. 3.

In the cockroach nymph stage test, the mortality rate was lower than that of adult cockroaches. Qian et al. (2010) proved that 6 week-old nymphs were more tolerant to dichlorvos and propoxur than the other ages tested, whereas both types of materials are chemical pesticides. The specific activity of acetylcholinesterase (AChE) took responsibility for this tolerance. Carbamate and organophosphate insecticides were like target sites for AChE. The inhibition of AChE by carbamate or organophosphate insecticides occurs via a reversible complex formation followed by carbamylation or phosphorylation. AChE is a key enzyme in the transmission of nerve impulses, specifically in termination of cholinergic synaptic transmission in mammals and insects. The primary mechanism of acute toxicity of carbamate and organophosphate insecticides has been reported as its inhibition of $\mathrm{AChE}$ in the cholinergic synapse of the nervous system of the cockroach. The specific activity of AChE decreased significantly with increasing age. Thus, the application of entomopathogenic fungi to cockroaches as a biocontrol was influenced by the age of the target insects.

In conclusion, there were 4 entomopathogenic fungi isolates obtained in this study consisting of 3 isolates of Aspergillus sp and 1 Penicillium sp. Chitin-degrading enzymes were used as key characteristics of candidate biocontrol agents against $P$. americana. Further testing of biocontrol activity on cockroaches using Aspergillus strains IK1 and IK3 showed the mortality of $P$. americana in both the nymph and adult stages. This study showed that the entomopathogenic fungi obtained was more effective in controlling cockroaches in the adult stage than nymphs.

\section{ACKNOWLEDGEMENTS}

We would like to express our gratitude and thanks to all side whom help and contribute for allowing us to conduct the research.

\section{REFERENCES}

Arifah F, Hestiningsih R, Rahadian R. 2016. Preferensi kecoak amerika Periplaneta americana (L.) (Blattaria: Blattidae) terhadap baiting gel. Jurnal Kesehatan Masyarakat Universitas Diponegoro 4 (4): 289297. [Indonesian]

Atiokeng Tatang RJ, Tsila HG, Wabo Poné J. 2017. Medically important parasites carried by cockroaches in Melong Subdivision, Littoral, Cameroon. J Parasitol Res 2017. DOI: 10.1155/2017/7967325.

Barnet HL, Hunter B. 1998. Illustrated Genera of Imperfect Fungi. 4th ed. Macmillian Publishing Company, London.

Berini F, Katz C, Gruzdev N, Casartelli M, Tettamanti G, Marinelli F. 2018. Microbial and viral chitinases: Attractive biopesticides for integrated pest management. Biotechnol Adv 36 (3): 818-838. DOI: 10.1016/j.biotechadv.2018.01.002.

Brzezinska MS, Jankiewicz U, Burkowska A, Walczak M. 2014. Chitinolytic microorganisms and their possible application in environmental protection. Curr Microbiol 68 (1): 71-81. DOI: 10.1007/s00284-013-0440-4.

Choudhary V, Jain PC. 2012. Screening of alkaline protease production by fungal isolates from different habitats of Sagar and Jabalpur district (MP). J Acad Ind Res 1 (4): 215-220.

Dhawan M, Joshi N. 2017. Enzymatic comparison and mortality of Beauveria bassiana against cabbage caterpillar Pieris brassicae LINN. Braz J Microbiol 48 (3): 522-529. DOI: 10.1016/j.bjm.2016.08.004.

Gutierrez AC, Gołębiowski M, Pennisi M, Peterson G, García JJ, Manfrino RG, López Lastra CC. 2015. Cuticle fatty acid composition and differential susceptibility of three species of cockroaches to the entomopathogenic fungi Metarhizium anisopliae (Ascomycota, Hypocreales). J Econ Entomol 108 (2): 752-60. DOI: $10.1093 /$ jee/tou096.

Jain A, Jain R, Jain S. 2020. Isolation of Coprophilous Fungi (Moist Chamber Method). In: Basic Techniques in Biochemistry, Microbiology and Molecular Biology. Springer Protocols Handbooks, Nederland. DOI: 10.1007/978-1-4939-9861-6_32. 
Lechuga EGO, Zapata IQ, Niño KA. 2016. Detection of extracellular enzymatic activity in microorganisms isolated from waste vegetable oil-contaminated soil using plate methodologies. Afr J Biotechnol 15(11): 408- 416. DOI: 10.5897/ajb2015.14991.

Litwin A, Nowak M, Różalska S. 2020. Entomopathogenic fungi: unconventional applications. Rev Environ Sci Biotechnol 19 (1): 23 42. DOI: $10.1007 / \mathrm{s} 11157-020-09525-1$.

Lopes RB, Martins I, Souza DA, Faria M. 2013. Influence of some parameters on the germination assessment of mycopesticides. J Invertebrate Pathol 112 (3): 236-242. DOI: 10.1016/j.jip.2012.12.010.

Mantzoukas S, Eliopoulos PA. 2020. Endophytic entomopathogenic fungi: A valuable biological control tool against plant pests. Appl Sci (Switzerland) 10 (1): 360. DOI: 10.3390/app10010360

Martindah E, Bahri S. 2016. Kontaminasi mikotoksin pada rantai makanan. $\quad$ Wartazoa $26 \quad$ (3): $115-124$ http://linkinghub.elsevier.com/retrieve/pii/S2211601X15001431

Moges F, Eshetie S, Endris M, Huruy K, Muluye D, Feleke T, Silassie FG, Ayalew G, Nagappan R. 2016. Cockroaches as a source of high bacterial pathogens with multidrug-resistant strains in Gondar Town, Ethiopia. BioMed Res Int 2016. DOI: 10.1155/2016/2825056.

Mongeau JM, Demir A, Dallmann CJ, Jayaram K, Cowan NJ, Full RJ 2014. Mechanical processing via passive dynamic properties of the cockroach antenna can facilitate control during rapid running. J Exp Biol 217 (18): 3333-3345. DOI: 10.1242/jeb.101501.

Nelly N, Syahrawati M, Hamid H, Habazar T, Gusnia DN. 2019. Diversity and characterization of entomopathogenic fungi from rhizosphere of maize plants as potential biological control agents. Biodiversitas 20 (5): 1435-1441. DOI: 10.13057/biodiv/d200536.

Nicolopoulou-Stamati P, Maipas S, Kotampasi C, Stamatis P, Hens L. 2016. Chemical pesticides and human health: The urgent need for a new concept in agriculture. Front Pub Health 4 (July): 1-8. DOI: 10.3389/fpubh.2016.00148

Perinotto WMS, Golo PS, Coutinho CJB, Sá FA, Santi L, Beys WO, Junges A, Vainstein MH, Schrank A, Salles CMC, Bittencourt VREP. 2014. Veterinary parasitology enzymatic activities and effects of mycovirus infection on the virulence of Metarhizium anisopliae in Rhipicephalus microplus. Vet Parasitol 203 (1-2): 189-196. DOI: 10.1016/j.vetpar.2014.02.011.

Praja RN, Yudhana A. 2018. Isolasi dan identifikasi Aspergillus spp pada paru-paru ayam kampung yang dijual di Pasar Banyuwangi. Jurnal Medik Veteriner 1 (1): 6. DOI: 10.20473/jmv.vol1.iss1.2017.6-11.

Qian K, Wei XQ, Zeng XP, Liu T, Gao XW. 2010. Stage-dependent tolerance of the German cockroach, Blattella germanica for dichlorvos and propoxur. J Insect Sci 10 (194): 1-10. DOI: 10.1673/031.010.20101.

Ratnaseelan AM, Tsilioni I, Theoharides TC. 2018. Effects of mycotoxin on neuropsychiatric symptoms and immune processes. Clin Ther 40 (6): 903-917. DOI: 10.1016/j.clinthera.2018.05.004.

Robles-Acosta, I. N., Chacón-Hernández, J. C., Torres-Acosta, R. I., Landeros-Flores, J., Vanoye-Eligio, V., \& Arredondo-Valdés, R. 2019. Entomopathogenic fungi as biological control agents of Phyllocoptruta oleivora (Prostigmata: Eriophyidae ) under greenhouse conditions entomopathogenic fungi as biological control agents of Phyllocoptruta oleivora (Prostigmata : Eriophyidae ) under grew. Fla Entomol 102 (2): 303-308.

Sanchez CJ, Chiu CW, Zhou Y, González JM, Vinson SB, Liang H. 2015. Locomotion control of hybrid cockroach robots. J Royal Soc Interface 12 (105). DOI: 10.1098/rsif.2014.1363.
Schiavone M, Vax A, Formosa C, Martin-Yken H, Dague E, François JM. 2014. A combined chemical and enzymatic method to determine quantitatively the polysaccharide components in the cell wall of yeasts. FEMS Yeast Res 14 (6): 933-947. DOI: 10.1111/15671364.12182.

Schuster E, Dunn-Coleman N, Frisvad J, Van Dijck P. 2002. On the safety of Aspergillus niger - A review. Appl Microbiol Biotechnol 59 (4-5): 426-435. DOI: $10.1007 / \mathrm{s} 00253-002-1032-6$

Septiana N, Rosa E, Ekowati CN. 2019. Efektivitas jamur entomopatogen sebagai bioinsektisida lalat rumah (Musca domestica). Biosfer: Jurnal Tadris Biologi 10 (1): 87-94. [Indonesian]

Soesanto L, Rahmaddila A, Hartono R, Mugiastuti E, Widarta H. 2020. Seed-borne pathogenic fungi on some soybean varieties. Biodiversitas 21 (9): 4010-4015. DOI: 10.13057/biodiv/d210911.

Supiyanto S, Rosa E, Irawan B, Nukmal N. 2019. Isolasi dan uji patogenitas isolat fungi entomopatogen terhadap stadium dewasa nyamuk Aedes aegypti. Jurnal Biologi Papua 11 (1): 33-41. DOI: 10.31957/jbp.832. [Indonesian]

Suryadi Y, Priyatno TP, Samudra IM, Susilowati DN, Lawati N, Kustaman E. 2016. Pemurnian parsial dan karakterisasi kitinase asal jamur entomopatogen Beauveria bassiana Isolat BB200109. Jurnal AgroBiogen 9 (2): 77. DOI: 10.21082/jbio.v9n2.2013.p77-84. [Indonesian]

Tuininga AR, Miller JL, Morath SU, Daniels TJ, Falco RC, Marchese M, Sahabi S, Rosa D, III KCS. 2009. Isolation of entomopathogenic fungi from soils and Ixodes scapularis (Acari: Ixodidae) ticks: prevalence and methods. J Med Entomol 46 (3): 557-565. DOI: 10.1161/CIRCULATIONAHA.110.956839.

Utami RS, Ambarwati R. 2014. Eksplorasi dan karakterisasi cendawan entomopatogen Beauveria bassiana dari Kabupaten Malang dan Magetan exploration and characterization of entomopathogenic fungi Beauveria bassiana from Malang and Magetan Regency. Lentera Bio 3 (1): 59-66. http://ejournal.unesa.ac.id/index.php/lenterabio

Veliz EA, Martínez-Hidalgo P, Hirsch MA. 2017. Chitinase-producing bacteria and their role in biocontrol. AIMS Microbiol 3 (3): 689-705. DOI: 10.3934/microbiol.2017.3.689.

Visagie CM, Houbraken J, Frisvad JC, Hong SB, Klaassen CHW, Perrone G, Seifert KA, Varga J, Yaguchi T, Samson RA. 2014. Identification and nomenclature of the genus Penicillium. Stud Mycol 78 (1): 343371. DOI: $10.1016 /$ j.simyco.2014.09.001.

$\mathrm{Yu}$ JH. 2010. Regulation of development in Aspergillus nidulans and Aspergillus fumigatus. Mycobiology 38 (4): $229 . \quad$ DOI: 10.4489/myco.2010.38.4.229.

Yunizar N. 2018. Patogenitas isolat jamur entomopatogenik Metarhizium anisopliae terhadap Lalat Rumah Musca domestica L . (Diptera: Muscidae ). Protobiont 7: 77-82.

Yusof AM. 2018. Identification of cockroaches as mechanical vector for parasitic infections and infestations in Kuantan, Malaysia. J Entomol 15 (3): 143-148. DOI: 10.3923/je.2018.143.148.

Zahraei-Ramazani AR, Saghafipour A, Vatandoost H. 2018. Control of American Cockroach (Periplaneta americana) in municipal sewage disposal system, Central Iran. J Arthropod-Borne Dis 12 (2): 172-179. DOI: $10.18502 /$ jad.v12i2.43.

Zain ME. 2011. Impact of mycotoxins on humans and animals. J Saudi Chem Soc 15 (2): 129-144. DOI: 10.1016/j.jscs.2010.06.006. 